\title{
Full 3D modeling of soil structure interaction by using solid finite elements
}

\author{
Halmat Ahmed Awla* and Muhammet Karaton** \\ * Department of Information Technology, Choman Technical Institute, Erbil Polytechnic University, Erbil, Iraq \\ ** Department of Civil Engineering, Faculty of Engineering, Firat University, Elazig, Turkey \\ *Corresponding Author: halmat.awlla@epu.edu.iq
}

Submitted :01/06/2020

Revised : :12/08/2021

Accepted : 23/08/2021

\begin{abstract}
Numerical studies for considering soil-structure interaction (SSI) are widely used to provide a better understanding of the seismic behavior of structures. The outcomes of these numerical studies are strongly depending on the input parameters. Back to the literature, for modelling different types of soil, there are convenient procedures whereby a single value of the Poisson's ratio is estimated for each type of soil; however, a range limitation between 0.10 and 0.40 is possible, and then other required parameters are determined utilizing the tables of the international seismic codes and the equations of the literature. In this article, a comprehensive parametric study was carried out with the aim of evaluating influences of the Poisson's ratio on the seismic behavior of structures, and sixteen values of Poisson's ratios were interpolated between 0.11 and 0.41 in order to examine all possible trails. For achieving this goal, a 4-story steel structure was analyzed on four different soil types (soft, stiff, very dense, and rock soils) under the El Centro acceleration record. The results in terms of time history top displacement and base shears have been discussed.
\end{abstract}

Keywords: Direct method; Substructure method; Soil types; Soil-structure interaction; Solid finite elements.

\section{INTRODUCTION}

Predicting a building's responses to seismic forces is one of the main challenges for structural and earthquake engineers. Although some analysis methods are available, there are still ongoing efforts to improve those methods in order to achieve better results. A significant parameter that can affect the seismic behavior of buildings is the property of the soil. Soil is a half-spaced medium that can affect structural responses and seismic waves. Basically, the fixedbase concept is assumed to be the analysis of structures. However, this hypothesis is only valid for structures built on hard soils. In fact, most of the structures are locating in soft soil zones; thus, the seismic behavior of these structures is affected by the flexibility of soft soils because of the kinematic and inertial interactions (Hokmabadi et al., 2014, Jayalekshmi et al., 2014, Raheem et al., 2015, Anand et al., 2018, Asli et al., 2019). For a given building with the change of soil types, different seismic responses are noticed, and the previously mentioned reciprocal effects between structure and soil are known as soil-structure interaction (SSI) (Asli et al., 2019).

Seismic behavior of soils totally builds upon the soil characteristics interms of some numerical parameters such as shear modulus, Poisson's ratio, modulus of elasticity, and damping ratio (Majedi et al., 2019), and some researchers 
have also stated that the above-mentioned parameters have significant impacts on the serviceability behavior under normal loading conditions as well as dynamic loads (Noolu et al., 2018, AKSOY et al., 2021, Li, 2021). Dutta et al. (2004) stated that the buildings with natural periods of 0.3 to $1 \mathrm{~s}$ are the most sensitive structures to the seismic waves. Researchers have shown that the slenderness ratio and the relative stiffness between soil and structure are influencing seismic responses. Furthermore, for the soils with shear wave velocity lower than $600 \mathrm{~m} / \mathrm{s}$, the effect of SSI becomes significant on the dynamic responses (Anestis S. Veletsos et al., 1974, Galal et al., 2008). There are two main methods for modeling SSI, substructure, and direct (finite element) methods (Asli et al., 2019); aside from the two main methods, macro element and data-based methods have also been introduced (Nova et al., 1991, Farfani et al., 2015), and the focus of the current study is on direct method. In a direct approach, the soil and structure are modeled together in a single step, and complex SSI problems can be modeled with this sophisticated method, but the method is known as a time-consuming and computationally expensive method. Numerous researchers have utilized this methodology to investigate SSI problems among them (Rayhani et al., 2008, H. R. Tabatabaiefar et al., 2010, Matinmanesh et al., 2011, RezaTabatabaiefar et al., 2013, Karapetrou et al., 2015, Rahgozar, 2015, Hokmabadi et al., 2016, Krishnamoorthy et al., 2016, Ghandil et al., 2017).

Bhojegowda et al. (2015) carried out a finite element analysis for a multistory structure, different soil conditions have been studied from soft to hard soils, and also different story levels, that is, 5, 10, and 15, were examined. The results of the study revealed that natural fundamental periods for flexible base models are higher than hard base ones; the same phenomenon is observed in the literature (Stewart\&Fenves\& et al., 1999, Stewart\&Seed\& et al., 1999). Guerdouh et al. (2019) performed a numerical analysis on the effect of SSI on dynamic responses of the single-story reinforced concrete frame structures, and different soil profiles have been examined. According to the outcomes of the study, the soil type has a great influence on the dynamic responses, and structures on soft soils showed higher horizontal displacements than the structures modeled on hard soils. The effect of fixed base and soil-structure interaction was investigated by Asli et al. (Asli et al., 2019, García, 2008, Awlla et al., 2020). An increase in the systems damping and fundamental period was observed for SSI models in comparison to the fixed base model. Bielak (Bielak, 1974, Anestis S Veletsos et al., 1974, Fatahi et al., 2011, Oz et al., 2020) stated that the fundamental periods are longer, and the damping ratios are higher for the structures resting on soils than for those with fixed-base. Tabatabaiefar et al. (Reza Tabatabaiefar et al., 2013) studied a 10-story moment-resisting frame structure under two base conditions: fixed-base (no SSI) and flexible-base (considering SSI with 3 soil types). According to the outcomes of the study, the base shear forces of the SSI models were less than those of the fixed-base condition. Many researchers also presented relevant work and valuable contributions in attempts to address parameters relating to SSI with dynamic responses of structures (Chopra et al., 1974, Bielak, 1976, Iguchi, 1978, Mekki et al., 2016, Behnamfar et al., 2017, Belletti et al., 2017, Venkatesh et al., 2017, Barnaure et al., 2019, Hökelekli et al., 2020, Awlla et al., 2021).

Back to the literature, to modeling soils (from soft to hard), well-known seismic codes are utilized. In the codes, a range limitation for the shear wave velocity $\left(\mathrm{V}_{\mathrm{s}}\right)$ is provided, ranging from 170 to $1130 \mathrm{~m} / \mathrm{s}$ for soft to hard soils. Thus, if the density of soil is known, shear modulus $\left(\mathrm{G}_{\mathrm{s}}\right)$ can be calculated using equation (1). Then, a value is assumed to Poisson's ratio. By relating Poisson's ratio and shear modulus in equation (2), the modulus of elasticity is determined for each soil types.

$$
\begin{aligned}
& V_{s}=\sqrt{\frac{G_{s}}{\rho}} \\
& G_{s}=\frac{E_{s}}{2(1+v)}
\end{aligned}
$$


In the body of literature, including all studies, only a value for Poisson's ratio is assumed for each soil type, while a range limitation is possible. The aim of the current research is to perform a comprehensive parametric study for considering all possible values for Poisson's ratios due to the fact that Poisson's value is an important parameter, as mentioned in the above procedure the shear modulus and modulus of elasticity depending on it. For this purpose, the seismic behavior of a 4-story steel structure under El Centro acceleration record and four different soil types (soft, stiff, very dense, and rock soils) were studied. El Centro acceleration curve is shown in Figure 1. The results in terms of time history top displacement and base shears have been discussed.

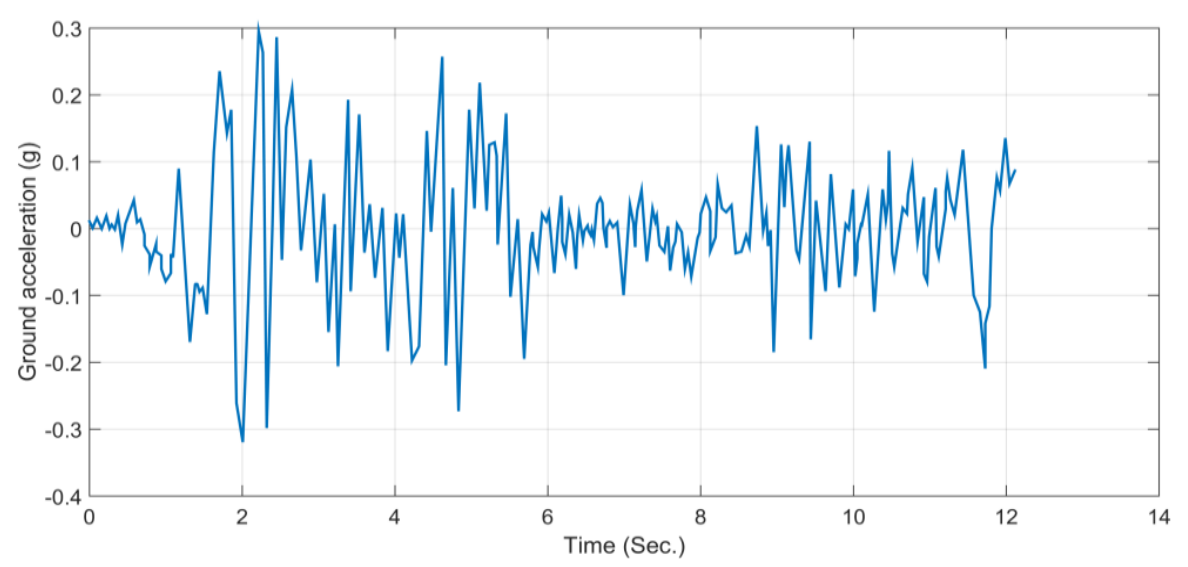

Figure 1. El Centro ground acceleration curve.

\section{NUMERICAL MODELLING}

Six different soil profiles (Hard rock, Rock, Very dense, Stiff, Soft, and Very soft) have been defined in the well-known seismic codes among them Uniform Building Code (UBC), American Society of Civil Engineers (ASCE), and International Building Code (IBC). According to the codes, there are not any data available for the sixth one since this soil profile does need a detailed specific site investigation; however, for the other soil profiles, a range limitation for shear wave velocity $\left(\mathrm{V}_{\mathrm{s}}\right)$, standard penetration test, and undrained shear strength test were provided. For the current research, Rock, Very dense, Stiff, and Soft soil profiles are studied for considering SSI into account.

Shear wave velocity $\left(\mathrm{V}_{\mathrm{s}}\right)$ for each soil profile was determined in the tables of the mentioned codes. Now, if the density of soil is known, then shear modulus $\left(\mathrm{G}_{\mathrm{s}}\right)$ can be calculated using equation (1). The density of soil can be easily estimated by the site engineer, and for the current work, the density of soil is assumed as $2000 \mathrm{~kg} / \mathrm{m}^{3}$ for all types of soils. Shear wave velocity and calculated shear modulus for different soil profiles are presented in Table 1.

Table 1. Shear wave velocity and shear modulus for different soil profiles.

\begin{tabular}{|c|c|c|}
\hline Soil profiles & Shear wave velocity- $\mathbf{V}_{\mathbf{s}}(\mathbf{m} / \mathbf{s})$ & Shear Modulus- $\mathbf{G}_{\mathbf{s}}$ (MPa) \\
\hline Rock & 1130 & 2553.8 \\
\hline Very dense & 560 & 627.2 \\
\hline Stiff & 270 & 145.8 \\
\hline Soft & 170 & 57.8 \\
\hline
\end{tabular}


According to many references, the value of Poisson's ratio for different soils is ranging between 0.1 and 0.4 (Kaniraj, 1988, Bowles, 1996, Terzaghi et al., 1996, Ameratunga et al., 2016). Thus, in this research, sixteen values of Poisson's ratios were assumed as $v=0.11, v=0.13, v=0.15, v=0.17, v=0.19, v=0.21, v=0.23, v=0.25, v=0.27$, $v=0.29, v=0.31, v=0.33, v=0.35, v=0.37, v=0.39$, and $v=0.41$ for each soil profile. By relating Poisson's ratio and shear modulus in equation (2), the modulus of elasticity was calculated for each soil profile and refined in Table 2.

Table 2. Modulus of elasticity in (MPa) for different soil profiles and Poisson's ratios.

\begin{tabular}{|c|c|c|c|c|c|c|c|c|c|c|c|c|c|c|c|c|}
\hline 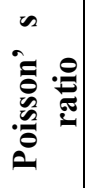 & 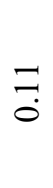 & $\frac{n}{0}$ & $\frac{n}{0}$ & $\frac{1}{0}$ & $\frac{\partial}{0}$ & $\tilde{\jmath}$ & $\tilde{\imath}$ & $\stackrel{\overbrace{}}{3}$ & $\widehat{ָ}$ & ֻे & $\tilde{m}$ & $\stackrel{m}{0}$ & थै? & $\hat{n}$ & సे? & $\vec{\nabla}$ \\
\hline 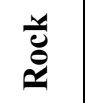 & $\begin{array}{l}\text { ठి } \\
\text { in }\end{array}$ & $\underset{i}{\stackrel{N}{n}}$ & 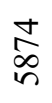 & $\frac{0}{2}$ & $\stackrel{\infty}{\stackrel{0}{8}}$ & $\stackrel{\infty}{6}$ & $\begin{array}{l}\text { D } \\
\text { ర్ర }\end{array}$ & $\begin{array}{l}n \\
\infty \\
\widetilde{\sigma}\end{array}$ & 同 & 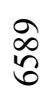 & $\overrightarrow{\hat{\sigma}}$ & $\hat{\sigma}$ & $\stackrel{n}{\alpha}$ & $\hat{\widehat{a}}$ & ஓे & ్ㅗㅇ \\
\hline 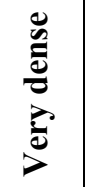 & ๙ૂ & $\stackrel{\infty}{\vec{J}}$ & $\stackrel{\mathscr{f}}{ \pm}$ & $\stackrel{\infty}{\stackrel{\infty}{+}}$ & 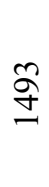 & $\stackrel{\infty}{n}$ & $\stackrel{?}{n}$ & $\begin{array}{l}\infty \\
\stackrel{0}{n} \\
\stackrel{n}{n}\end{array}$ & $\hat{n}$ & $\stackrel{\infty}{0}$ & $\underset{\sigma}{\tilde{g}}$ & 冓 & $\hat{\delta}$ & $\stackrel{2}{\equiv}$ & $\underset{I}{ \pm}$ & వ \\
\hline 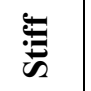 & $\underset{\sim}{\stackrel{\Delta}{~}}$ & లి & $\stackrel{n}{m}$ & $\vec{\sim}$ & 守 & $\stackrel{n}{n}$ & ñ & $\underset{n}{n}$ & 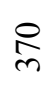 & $\frac{0}{m}$ & $\underset{\sim}{\infty}$ & $\underset{\substack{\infty \\
\infty}}{ }$ & స్ & बे & ?o & $\bar{\nabla}$ \\
\hline ڤ્ & $\stackrel{\infty}{\simeq}$ & 을 & $\stackrel{m}{m}$ & $\stackrel{n}{n}$ & $\stackrel{\infty}{=}$ & 온 & $\stackrel{\mathcal{I}}{ \pm}$ & $\stackrel{n}{ \pm}$ & 守 & $\stackrel{g}{ \pm}$ & $\bar{n}$ & $\tilde{n}$ & $\stackrel{2}{n}$ & $\stackrel{\infty}{n}$ & $\bar{\sigma}$ & ชె \\
\hline
\end{tabular}

For each soil profile, sixteen numerical cases were created as Case-1, Case-2, Case-3, Case-4, Case-5, Case-6, Case-7, Case-8, Case-9, Case-10, Case-11, Case-12, Case-13, Case-14, Case-15, and Case-16 for Poisson's ratios $v=0.11, v=0.13, v=0.15, v=0.17, v=0.19, v=0.21, v=0.23, v=0.25, v=0.27, v=0.29, v=0.31, v=0.33, v=0.35, v=0.37$, $\nu=0.39$, and $v=0.41$, respectively.

\section{Description of the Structure}

A four-story steel structure with two bays in each orthogonal direction on a big soil medium was modelled with the aid of finite element method Figure 2. The center to center length of each bay and story heights are defined as $4 \mathrm{~m}$ and 3m, respectively. W12X106 and W12X72 steel standard sections were utilized for modelling the columns of the first two lower stories and the other two upper stories, respectively. Beams were modelled with W12X50 steel sections. A total ultimate load of $1.8 \mathrm{ton} / \mathrm{m}^{2}$ was defined to the floors including self-weight. 


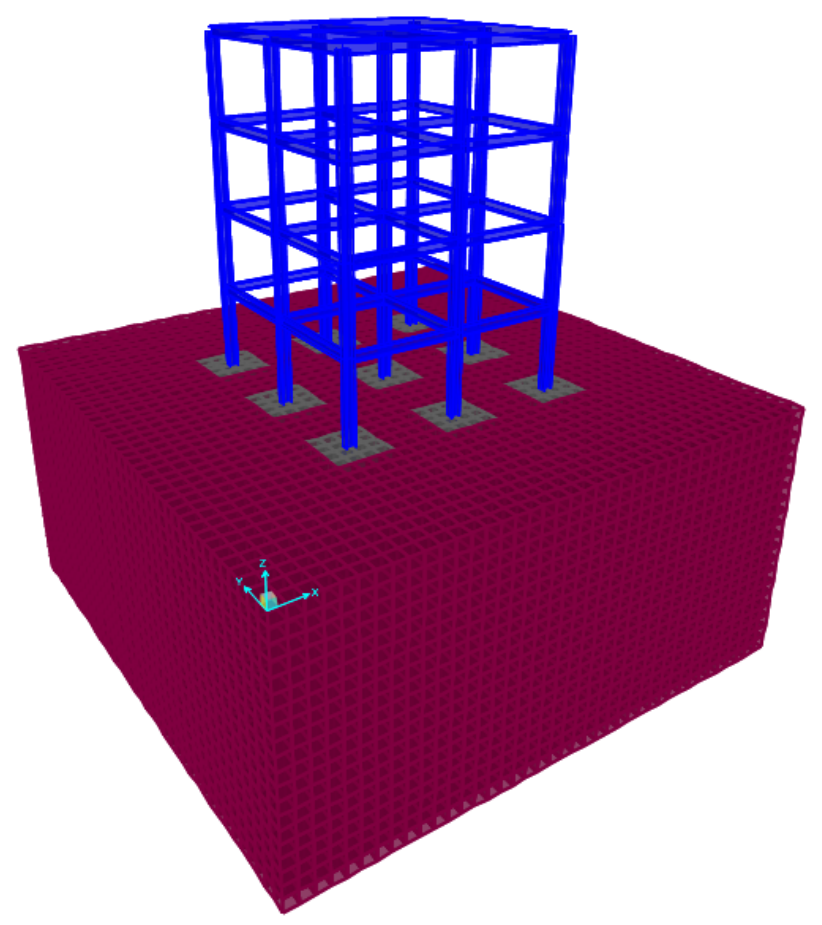

Figure 2. General layout of the structure.

The big soil medium was modelled by means of eight-node brick solid finite elements that each node has three translational degrees of freedom, with meshing size of $0.5 \times 0.5 \times 0.5 \mathrm{~m}$, and the dimensions of the underneath soil are 20x20x10 m. Thus, the total number of 32000 cubic finite elements was used. Fixed base boundary was assigned to the base finite element meshes of the model, while the roller boundary was used for the vertical faces, based on the previous suggestions (Kramer, 1996, Yoo, 2013, Torabi et al., 2014). For considering inelasticity of the frame structures, two main modeling approaches are available, that is,distributed plasticity method and lumped plasticity method. In the first type of element modeling, two zero-length nonlinear rotation springs are connected by an elastic beam/column element. The spring computes nonlinear behavior during loading. The second one discretizes the sections into fibers and the length into integration points; it is so-called fiber element modeling (Karaton et al., 2018, Awla, 2019). For this study, the first method was utilized. Plastic hinges are defined to the ends of the building elements for representing nonlinearity, and the underneath soil is defined as an elastic material; however, the soil nonlinearity consideration is a straightforward action for the next studies. SAP2000 software package was used for the dynamic analysis. The program is known as a user-friendly interface and the most common finite element software in structural engineering community.

\section{RESULTS AND DISCUSSION}

The obtained dynamic responses results in terms of base shear and top story displacements of all sixteen numerical cases for each soil profile are presented in Figure 4 to Figure 11. The level of dynamic responses affected by the embedment of different soils and different numerical cases was computed by making a comparison study. In the study, nineteen maximum pick points were selected on the time history top displacement and base shear graphs for calculating difference ratio between the responses of numerical cases, as shown in Figure 3. Numerical case-8 with the Poisson's ratio of 0.25 is the median case; thus, the dynamic responses of other fifteen numerical cases were 
compared to case- 8 in order to determine the percentage differences of each case in the perspective of case- 8 . The ratio of the differences was determined in an average manner by using equations (3) and (4).
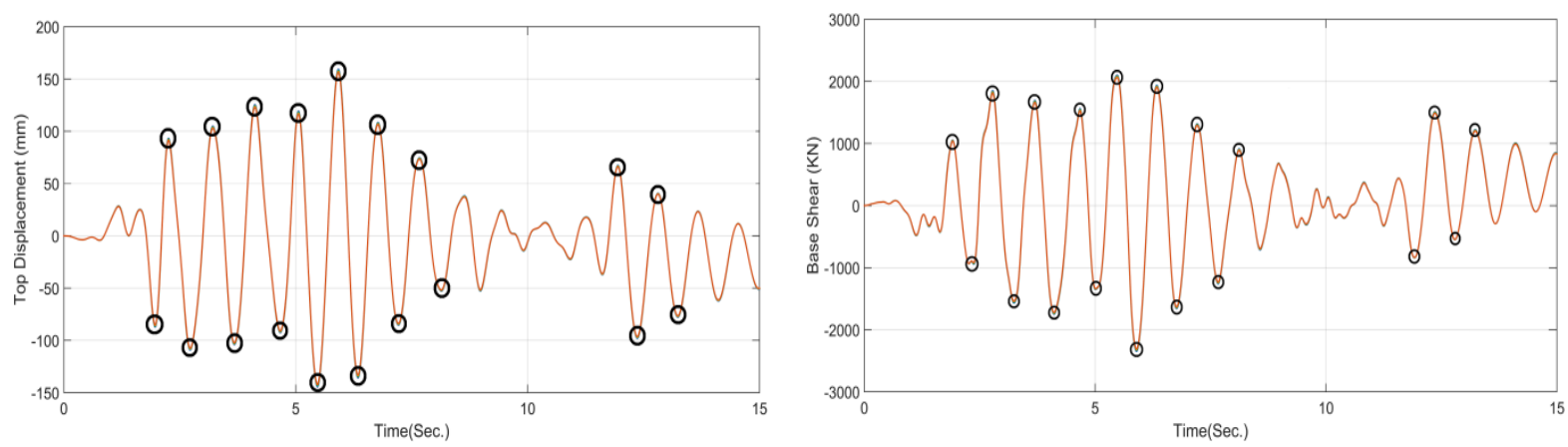

Figure 3. The selected nineteen maximum: (a) top displacement and (b) base shear points.

$$
\begin{aligned}
& \Delta_{\text {dis }}=\frac{\sum_{i=1}^{n} \delta_{\text {case }-1, i}-\delta_{\text {case }-16, i}}{n} \\
& \Delta_{b, \text { shear }}=\frac{\sum_{j=1}^{m} b_{\text {case }-1, j}-b_{\text {case }-16, j}}{m}
\end{aligned}
$$

where $n$ and $m$ are sample point number of displacement and base shear on the time history graphs, respectively. $\delta_{\text {case-1,i }}$ and $\delta_{\text {case }-16, i}$ are values of $i^{\text {th }}$ the peak point on displacement time history graph of numerical Case- 1 to Case-16, respectively. $b_{\text {case }-1, j}$ and $b_{\text {case }-16, j}$ are $j^{\text {th }}$ the peak points on base shear time history graph of numerical Case-1 to Case-16, respectively.

The obtained top story displacements and base shear results for rock soil profile cases are presented in

Figure 4 and Figure 5. According to the performed comparison study, it has been observed that the numerical cases of structures embedded by rock soil profile have almost identical results, and the ratio of differences between the numerical case- 8 and the maximum case among other remains cases for top story displacement and base shears did not exceed $0.6 \%$ and $0.5 \%$, respectively; however, this difference ratio was gradually increased towards the softer soil cases. The determined top displacements and base shear results for the structures that were embedded by very dense, stiff, and soft soils are shown in Figure 6 to Figure 11. According to the comparison study, it has been observed that the difference between numerical case- 8 and other cases for top story displacements is $2.4 \%, 11 \%$, and $27.9 \%$; on the other hand, these dissimilarities for base shears were $2.1 \%, 19.7 \%$, and $28.4 \%$ for very dense, stiff, and soft soil cases, respectively. The results of this study affirmed the same results obtained in (Galal et al., 2008, Maheshwari et al., 2011, S. H. R. Tabatabaiefar et al., 2013), and when shear wave velocity of a soil profile is less than $600 \mathrm{~m} / \mathrm{s}$, the effect of the SSI becomes significant on the dynamic response of structural systems. 


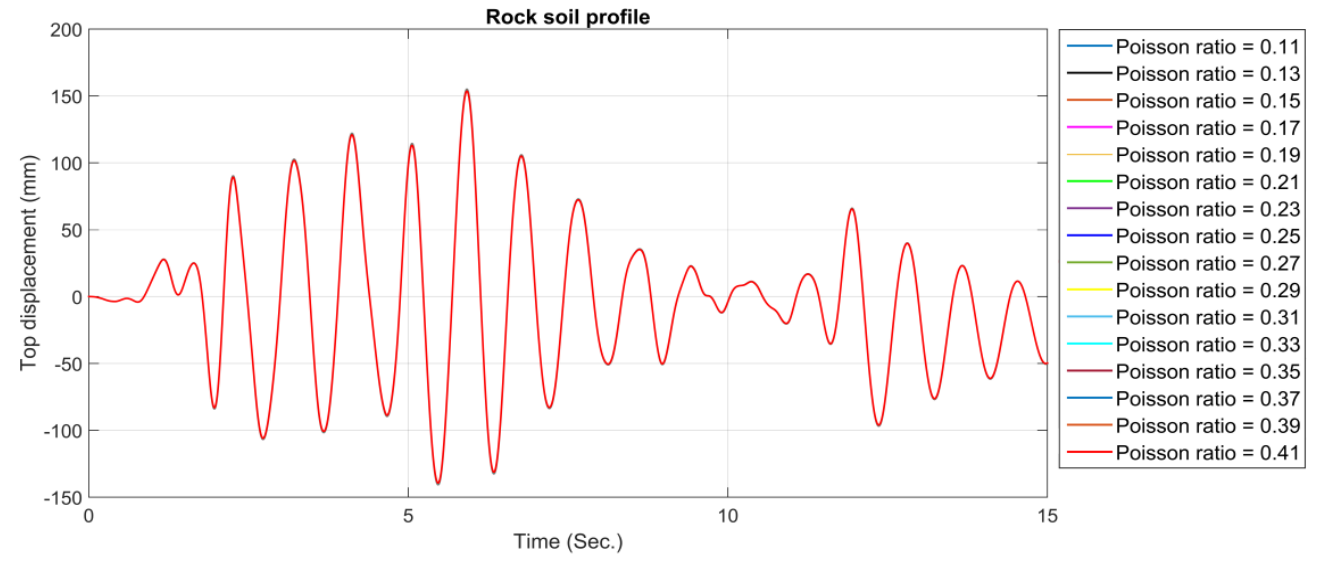

Figure 4. Top displacement for different Poisson's ratio values in rock soil profile.

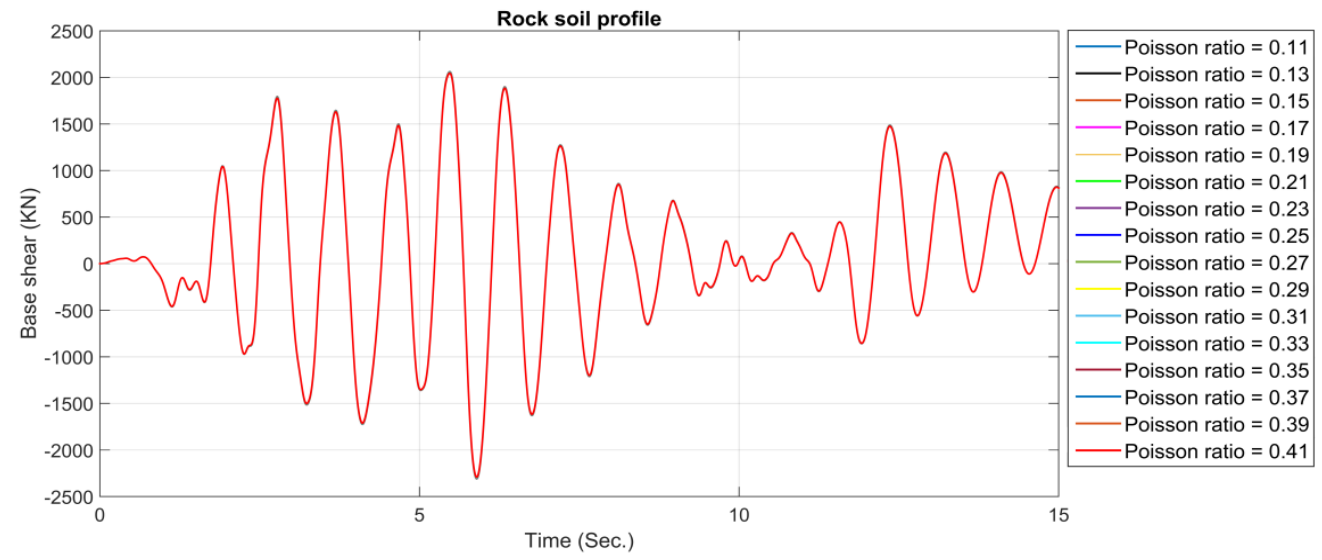

Figure 5. Base shear for different Poisson's ratio values in rock soil profile.

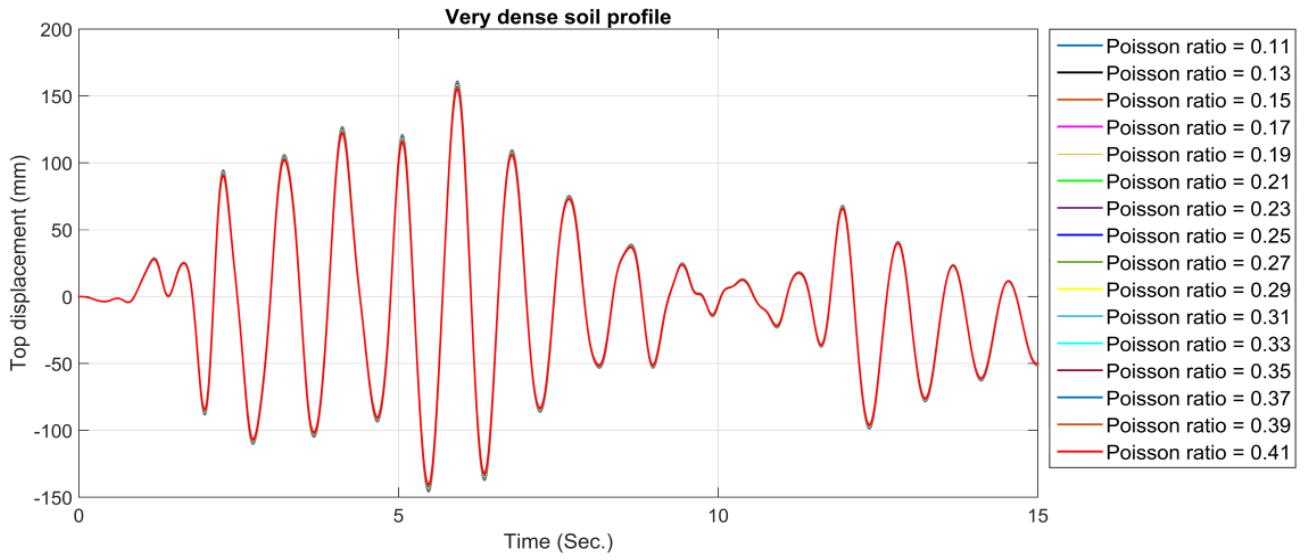

Figure 6. Top displacement for different Poisson's ratio values in very dense soil profile. 


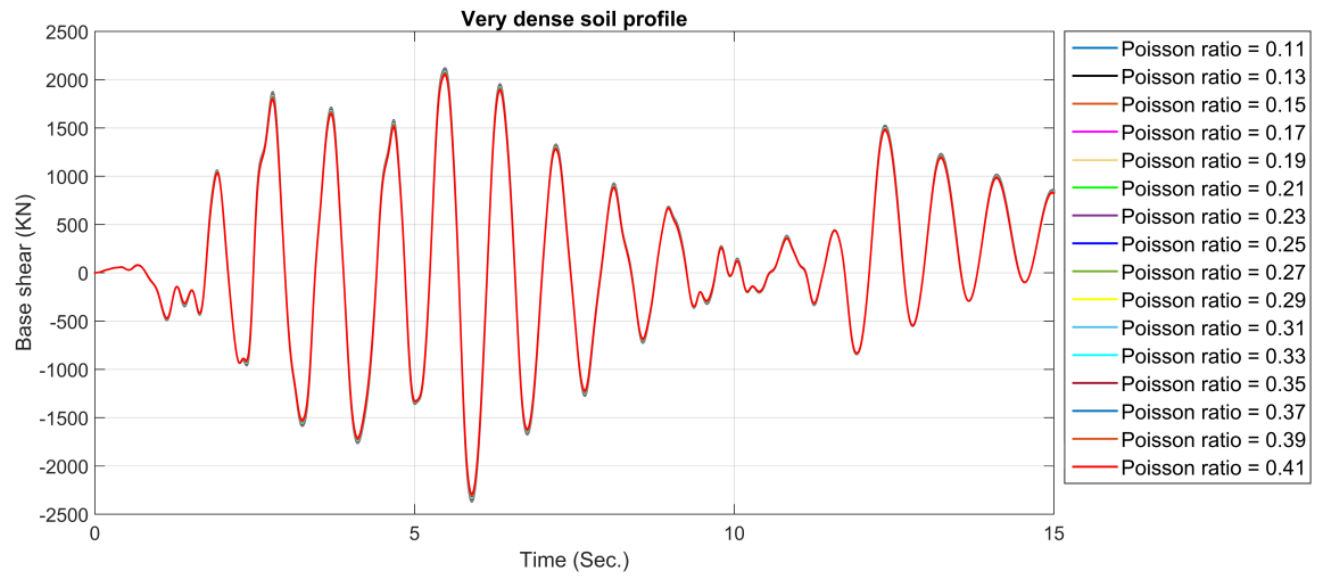

Figure 7. Base shear for different Poisson's ratio values in very dense soil profile.

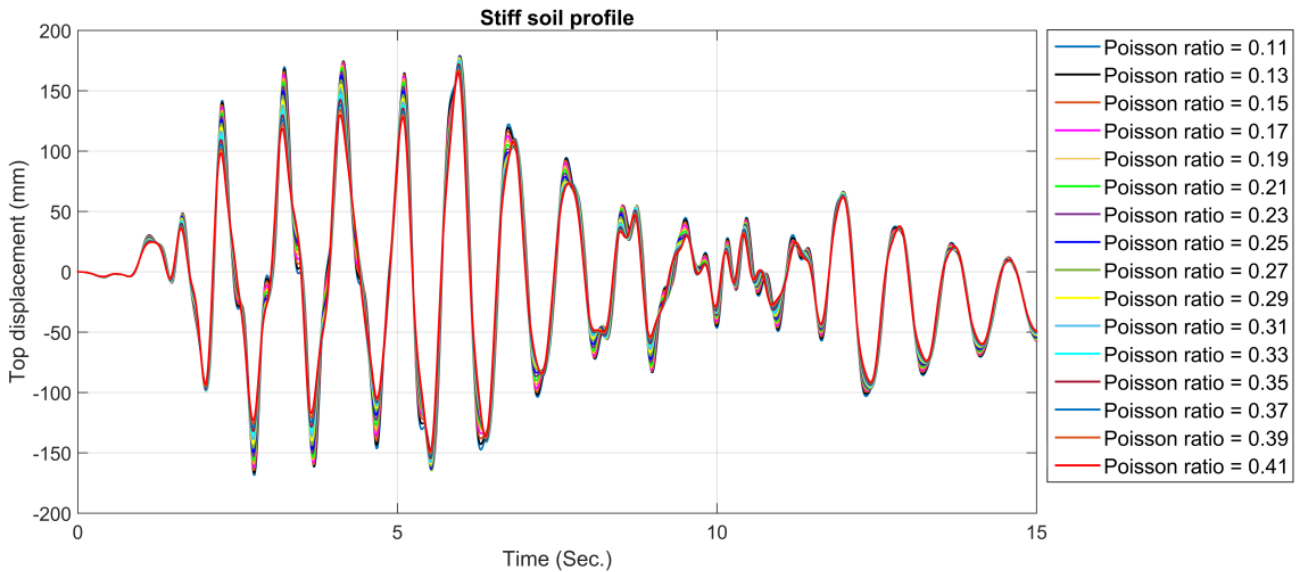

Figure 8. Top displacement for different Poisson's ratio values in stiff soil profile.

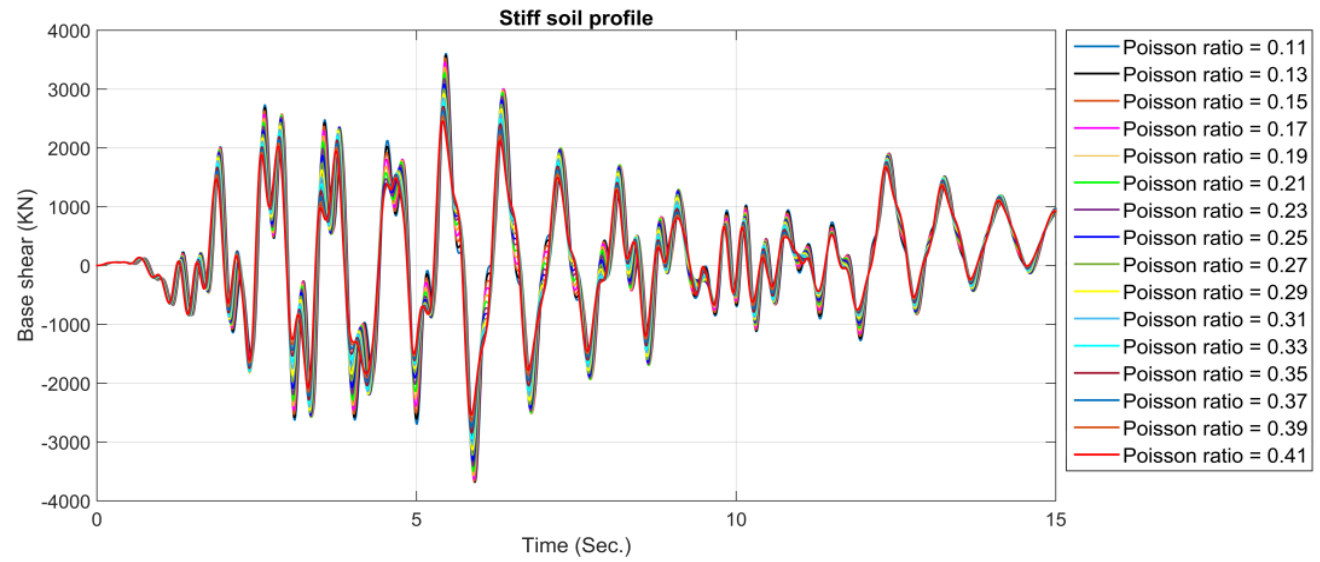

Figure 9. Base shear for different Poisson's ratio values in stiff soil profile. 


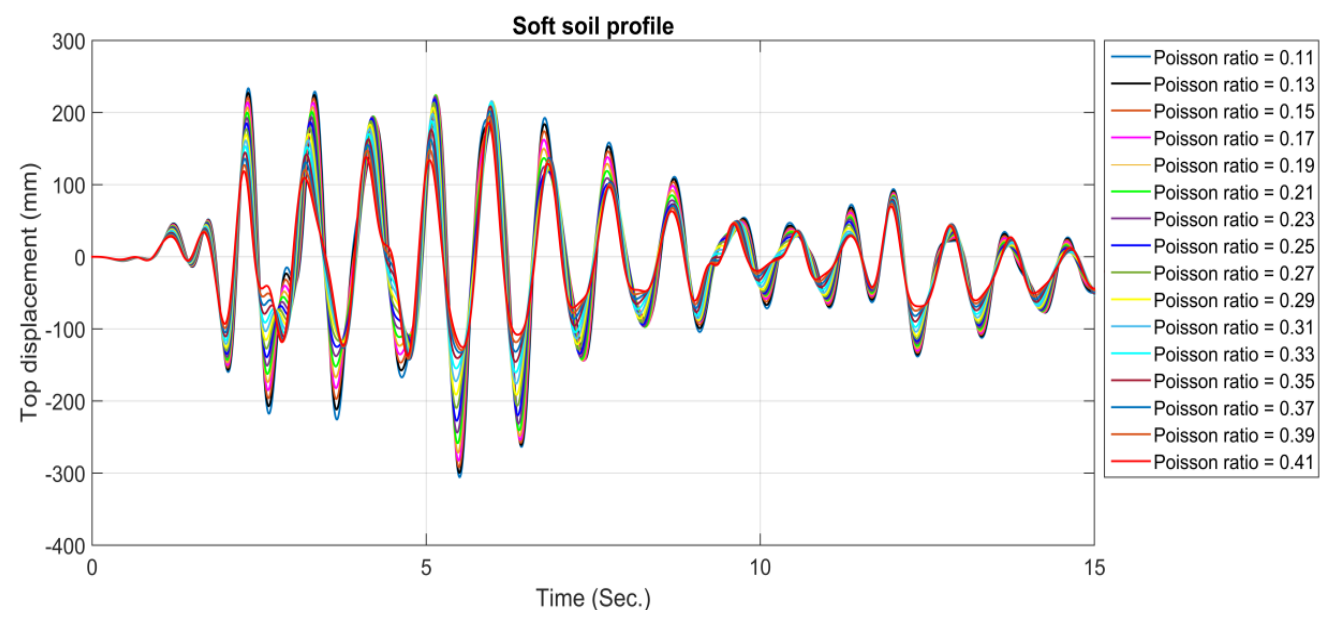

Figure 10. Top displacement for different Poisson's ratio values in soft soil profile.

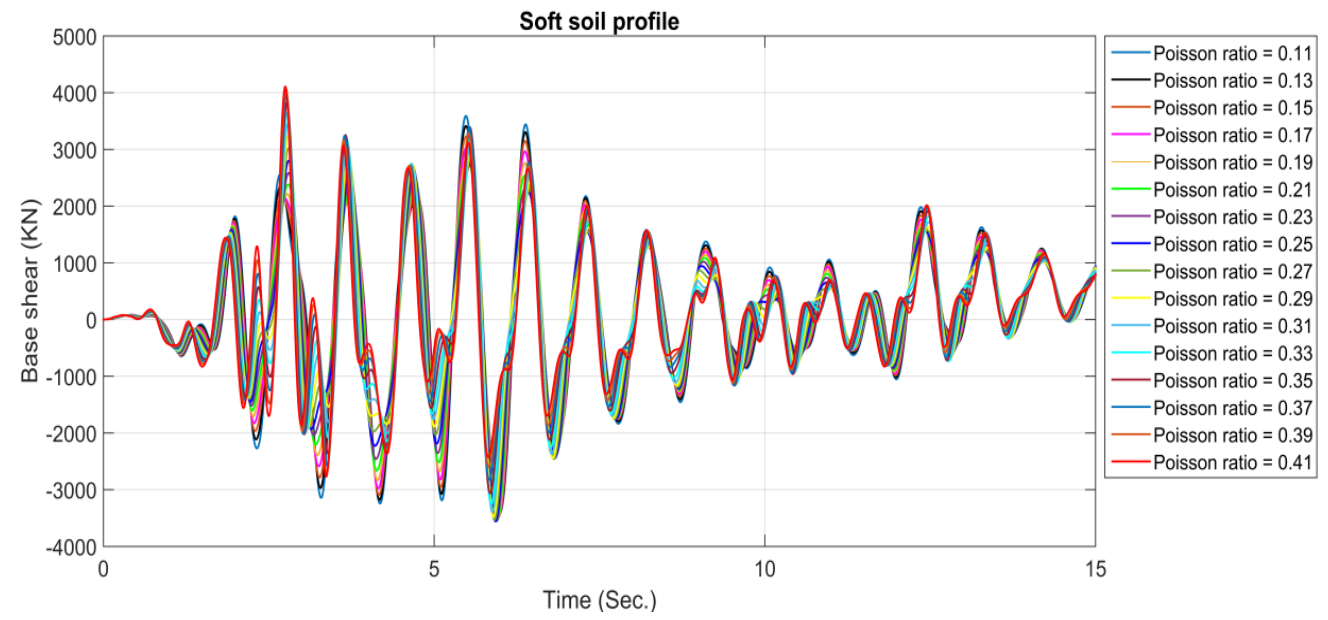

Figure 11. Base shear for different Poisson's ratio values in soft soil profile.

The results presented in Figure 4 to Figure 11 are showing how input parameters could affect the seismic behavior of structures when SSI is considered. As shown in Figure 12, assuming that Poisson's value for rock and very dense soil cases has minimum effect on the dynamic responses, maximum differences would not exceed $2.4 \%$; however, this effect becomes more sensitive towards softer soils, and the maximum deviations are $19.7 \%$ and $28.4 \%$ for stiff and soft soil cases. In summary, it can be concluded that, in the SSI problems for predicting accurate seismic responses, Poisson's value can be assumed for very dense and harder soils, while for stiff and softer soils, the actual values are required. 


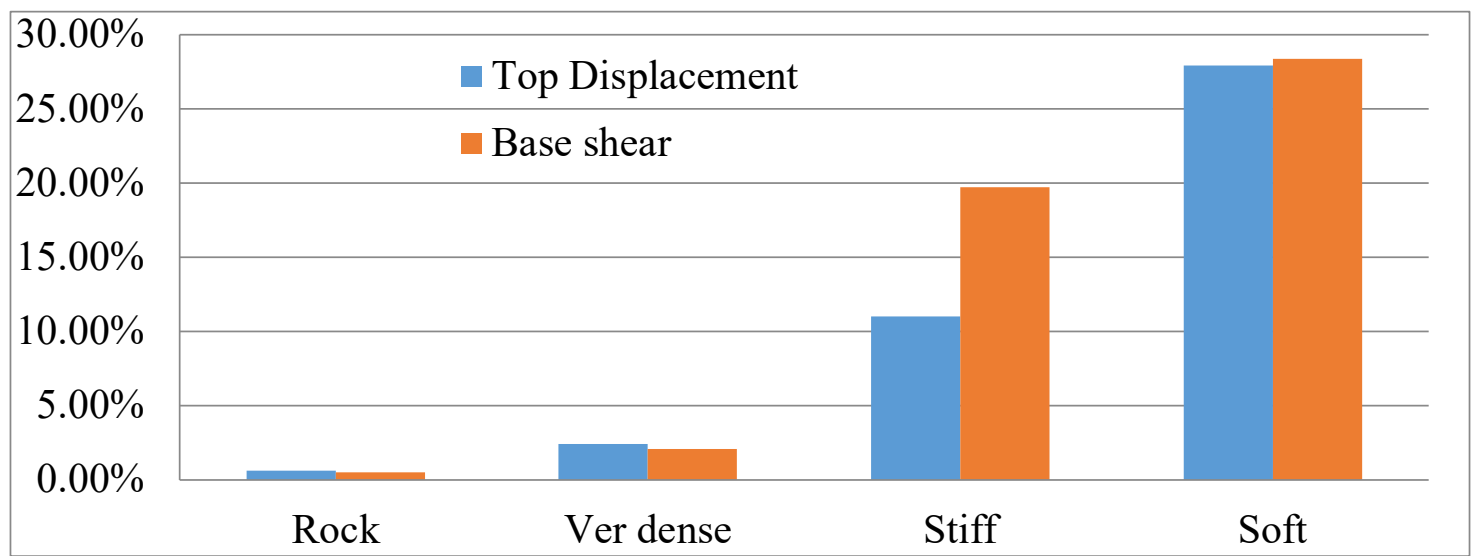

Figure 12. Maximum percentage difference for top displacement and base shear obtained for each soil profile.

\section{CONCLUSION}

According to the results of the current study, the following conclusions can be drawn:

- For the numerical cases embedded by rock, very dense, stiff, and soft soils, the maximum difference ratios for top story displacements were $0.6 \%, 2.4 \%, 11 \%$, and $27.9 \%$, respectively. However, these difference ratios for base shears were $0.5 \%, 2.1 \%, 19.7 \%$, and $28.4 \%$, respectively.

- In modelling SSI problems, Poisson's value can be assumed for very dense and harder soils, while for stiff and softer soils, the actual values are required for predicting accurate seismic responses.

- The results of this research affirmed the same results obtained in (Galal et al., 2008, Maheshwari et al., 2011, S. H. R. Tabatabaiefar et al., 2013), and when shear wave velocity of a soil profile is less than 600 $\mathrm{m} / \mathrm{s}$, the effect of the SSI becomes significant on the dynamic responses of structural systems.

\section{REFERENCES}

Hokmabadi, A. S., Fatahi, B. \& Samali, B. 2014. Assessment of soil-pile-structure interaction influencing seismic response of mid-rise buildings sitting on floating pile foundations. Computers and Geotechnics, 55, 172-186.

Jayalekshmi, B. \& Chinmayi, H. 2014. Effect of soil flexibility on seismic force evaluation of RC framed buildings with shear wall: A comparative study of IS 1893 and EUROCODE8. Journal of Structures, 2014.

Raheem, S. E. A., Ahmed, M. M. \& Alazrak, T. M. 2015. Evaluation of soil-foundation-structure interaction effects on seismic response demands of multi-story MRF buildings on raft foundations. International Journal of Advanced Structural Engineering (IJASE), 7(1), 11-30.

Anand, V. \& Kumar, S. S. (2018). Seismic soil-structure interaction: a state-of-the-art review. Paper presented at the Structures

Asli, S. J., Saffari, H., Zahedi, M. J. \& Saadatinezhad, M. 2019. Comparing the performance of substructure and direct methods to estimate the effect of SSI on seismic response of mid-rise structures. International Journal of Geotechnical Engineering. 
Majedi, P., Akbulut, S. \& Kurt, Z. N. 2019. Some geotechnical properties and damping ratio of clay nanocomposites. Journal of Engineering Research, 7(1).

Noolu, V. \& Pillai, R. J. 2018. Multi-scale laboratory investigation on black cotton soils stabilized with calcium carbide residue and fly ash. Journal of Engineering Research, 6(4).

AKSOY, H. S., TAHER, N. \& AWLLA, H. A. 2021. Shear strength parameters of sand-tire chips mixtures. Gümüşhane Üniversitesi Fen Bilimleri Enstitüsü Dergisi, 11(3), 713-720.

Li, B. 2021. Failure of an under-dip shale slope and its response under excavation conditions. Journal of Engineering Research, 9(1).

Dutta, S. C., Bhattacharya, K. \& Roy, R. 2004. Response of low-rise buildings under seismic ground excitation incorporating soil-structure interaction. Soil Dynamics and Earthquake Engineering, 24(12), 893-914.

Veletsos, A. S. \& Meek, J. W. 1974. Dynamic behaviour of building-foundation systems. Earthquake Engineering and Structural Dynamics, 3(2), 121-138. doi: https://doi.org/10.1002/eqe.4290030203.

Galal, K. \& Naimi, M. 2008. Effect of soil conditions on the response of reinforced concrete tall structures to near-fault earthquakes. The Structural Design of Tall and Special Buildings, 17(3), 541-562. doi: https://doi.org/10.1002/tal.365.

Nova, R. \& Montrasio, L. 1991. Settlements of shallow foundations on sand. Géotechnique, 41(2), 243-256.

Farfani, H. A., Behnamfar, F. \& Fathollahi, A. 2015. Dynamic analysis of soil-structure interaction using the neural networks and the support vector machines. Expert Systems with Applications, 42(22), 8971-8981.

Rayhani, M. \& EI Naggar, M. H. 2008. Numerical modeling of seismic response of rigid foundation on soft soil. International Journal of Geomechanics, 8(6), 336-346.

Tabatabaiefar, H. R. \& Massumi, A. 2010. A simplified method to determine seismic responses of reinforced concrete moment resisting building frames under influence of soil-structure interaction. Soil Dynamics and Earthquake Engineering, 30(11), 1259-1267.

Matinmanesh, H. \& Asheghabadi, M. S. 2011. Seismic analysis on soil-structure interaction of buildings over sandy soil. Procedia Engineering, 14, 1737-1743.

RezaTabatabaiefar, S. H., Fatahia, B. \& Samali, B. 2013. Lateral seismic response of building frames considering dynamic soil-structure interaction effects. Structural Engineering and Mechanics.

Karapetrou, S., Fotopoulou, S. \& Pitilakis, K. 2015. Seismic vulnerability assessment of high-rise non-ductile RC buildings considering soil-structure interaction effects. Soil Dynamics and Earthquake Engineering, 73, $42-57$.

Rahgozar, M. 2015. Accounting for soil nonlinearity in three-dimensional seismic structure-soilstructureinteraction analyses of adjacent tall buildings structures. International Journal of Civil Engineering, 13(3), 213-225.

Hokmabadi, A. S. \& Fatahi, B. 2016. Influence of foundation type on seismic performance of buildings considering soil-structure interaction. International Journal of structural stability and dynamics, 16(08), 1550043.

Krishnamoorthy, A. \& Anita, S. (2016). Soil-structure interaction analysis of a FPS-isolated structure using finite element model. Paper presented at the Structures

Ghandil, M. \& Behnamfar, F. 2017. Ductility demands of MRF structures on soft soils considering soil-structure interaction. Soil Dynamics and Earthquake Engineering, 92, 203-214.

Bhojegowda, V. \& Subramanya, K. 2015. Soil structure interaction of framed structure supported on different types of foundation. International Research journal of engineering and technology, 2(5), 651-660. 
Stewart, J. P., Fenves, G. L. \& Seed, R. B. 1999. Seismic soil-structure interaction in buildings. I: Analytical methods. Journal of Geotechnical and Geoenvironmental Engineering, 125(1), 26-37.

Stewart, J. P., Seed, R. B. \& Fenves, G. L. 1999. Seismic soil-structure interaction in buildings. II: Empirical findings. Journal of Geotechnical and Geoenvironmental Engineering, 125(1), 38-48.

Guerdouh, D. \& Khalfallah, S. 2019. Effect of soil-structure interaction on seismic performance of frame structures (In Spanish). Revista de la construcción, 18(2), 349-363.

García, J. A. (2008). Soil structure interaction in the analysis and seismic design of reinforced concrete frame buildings. Paper presented at the Proceedings of the fourteenth World Conference on Earthquake Engineering

Awlla, H. A., Taher, N. R. \& Mawlood, Y. I. 2020. Effect of Fixed-Base and Soil Structure Interaction on the Dynamic Responses of Steel Structures. International Journal of Emerging Trends in Engineering Research, $8(9)$.

Bielak, J. 1974. Dynamic behaviour of structures with embedded foundations. Earthquake Engineering \& Structural Dynamics, 3(3), 259-274.

Veletsos, A. S. \& Meek, J. W. 1974. Dynamic behaviour of building-foundation systems. Earthquake Engineering \& Structural Dynamics, 3(2), 121-138.

Fatahi, B., Tabatabaiefar, H. R. \& Samali, B. 2011. Performance based assessment of dynamic soil-structure interaction effects on seismic response of building frames Geo-Risk 2011: Risk Assessment and Management (pp. 344-351).

Oz, I., Senel, S. M., Palanci, M. \& Kalkan, A. 2020. Effect of Soil-Structure Interaction on the Seismic Response of Existing Low and Mid-Rise RC Buildings. Applied Sciences, 10(23), 8357.

Reza Tabatabaiefar, S. H., Fatahi, B. \& Samali, B. 2013. Seismic behavior of building frames considering dynamic soil-structure interaction. International Journal of Geomechanics, 13(4), 409-420.

Chopra, A. K. \& Gutierrez, J. A. 1974. Earthquake response analysis of multistorey buildings including foundation interaction. Earthquake Engineering \& Structural Dynamics, 3(1), 65-77.

Bielak, J. 1976. Modal analysis for building-soil interaction. Journal of the Engineering Mechanics Division, 102(5), 771-786.

Iguchi, M. (1978). Dynamic interaction of soil-structure with elastic rectangular foundation. Paper presented at the Proc. 5th Japan Earthq. Eng. Symp.

Mekki, M., Elachachi, S., Breysse, D. \& Zoutat, M. 2016. Seismic behavior of RC structures including soilstructure interaction and soil variability effects. Engineering Structures, 126, 15-26.

Behnamfar, F. \& Alibabaei, H. 2017. Classical and non-classical time history and spectrum analysis of soilstructure interaction systems. Bulletin of Earthquake Engineering, 15(3), 931-965.

Belletti, B., Gasperi, A., Spagnoli, A. \& Valentino, R. 2017. Role of soil-structure interaction on the response of precast RC structures under seismic loading: case study. Practice periodical on structural design and construction, 22(1), 04016014.

Venkatesh, M. \& Deshpande, R. 2017. Analysis of RC building frame with raft foundation considering soil structure interaction. International Research journal of engineering and technology, 4(05), 752-760.

Barnaure, M. \& Manoli, D. (2019). Unfavourable seismic behaviour of reinforced concrete structures due to soil structure interaction. Paper presented at the IOP Conference Series: Earth and Environmental Science

Hökelekli, E. \& Al-Helwani, A. 2020. Effect of soil properties on the seismic damage assessment of historical masonry minaret-soil interaction systems. The Structural Design of Tall and Special Buildings, 29(2), e1694. 
Awlla, H. A., Taher, N. R. \& Aksoy, S. H. 2021. Effect of SSI and Fixed-base Concept on the Dynamic Responses of Masonry Bridge Structures, Dalal Bridge as a Case Study. Academic Journal of Nawroz University (AJNU), 10(3).

Kaniraj, S. R. 1988. Design aids in soil mechanics and foundation engineering: Tata McGraw-Hill.

Bowles, L. 1996. Foundation analysis and design: McGraw-Hill.

Terzaghi, K., Peck, R. B. \& Mesri, G. 1996. Soil mechanics in engineering practice: John Wiley \& Sons.

Ameratunga, J., Sivakugan, N. \& Das, B. M. 2016. Correlations of soil and rock properties in geotechnical engineering: Springer.

Kramer, S. L. 1996. Geotechnical earthquake engineering: Upper Saddle River, N.J Prentice Hall 1996.

Yoo, C. 2013. Interaction between tunneling and bridge foundation - A 3D numerical investigation. Computers and Geotechnics, 49, 70-78. doi: https://doi.org/10.1016/j.compgeo.2012.11.005.

Torabi, H. \& Rayhani, M. T. 2014. Three dimensional finite element modeling of seismic soil-structure interaction in soft soil. Computers and Geotechnics, 60, 9-19. doi: https://doi.org/10.1016/j.compgeo.2014.03.014.

Karaton, M. \& Awla, H. A. 2018. Numerical investigation of the effect on ultimate loading capacity of different longitudinal reinforcement ratios of a RC portal frame. Journal of Structural Engineering \& Applied Mechanics, 1(3), 147-154. doi: https://doi.org/10.31462/jseam.2018.03147154.

Awla, H. A. 2019. Investigation of a reverse engineering method for determination of material properties of damaged or collapsed reinforced concrete building. Msc Thesis: Firat University, Faculty of Engineering, Civil Engineering Department. doi: https://tez.yok.gov.tr/UlusalTezMerkezi/tezDetay.jsp?id=oTG-SJCovATsQtvTqqs_g\&no=_qMBvwpGFpN-mp63emidog.

Maheshwari, B. K. \& Sarkar, R. 2011. Seismic Behavior of Soil-Pile-Structure Interaction in Liquefiable Soils: Parametric Study. International Journal of Geomechanics, 11(4), 335-347. doi: https://doi.org/10.1061/(ASCE)GM.1943-5622.0000087.

Tabatabaiefar, S. H. R., Fatahi, B. \& Samali, B. 2013. Seismic behavior of building frames considering dynamic soil-structure interaction. International Journal of Geomechanics, 13(4), 409-420. doi: https://doi.org/10.1061/(ASCE)GM.1943-5622.0000231. 